\title{
Reviewing the Benefits of Grazing/Browsing Semiarid Rangeland Feed Resources and the Transference of Bioactivity and Pro-Healthy Properties to Goat Milk and Cheese: Obesity, Insulin Resistance, Inflammation and Hepatic Steatosis Prevention
}

\author{
Claudia Delgadillo-Puga ${ }^{1, *}$ and Mario Cuchillo-Hilario ${ }^{1,2, * \text { (I) }}$ \\ 1 Departamento de Nutrición Animal Dr. Fernando Pérez-Gil Romo, Instituto Nacional de Ciencias Médicas y \\ Nutrición Salvador Zubirán (INCMNSZ), Tlalpan 14080, Ciudad de México, México \\ 2 Departamento de Ciencias Pecuarias, Facultad de Estudios Superiores de Cuautitlán, Universidad Nacional \\ Autónoma de México, Cuatitlán Izcalli 54714, Estado de México, México \\ * Correspondence: claudia.delgadillop@incmnsz.mx (C.D.-P.); mario.cuchilloh@incmnsz.mx (M.C.-H.); \\ Tel.: +52-55-54870900 (ext. 2820-2824) (C.D.-P.)
}

check for

updates

Citation: Delgadillo-Puga, C.; Cuchillo-Hilario, M. Reviewing the Benefits of Grazing/Browsing Semiarid Rangeland Feed Resources and the Transference of Bioactivity and Pro-Healthy Properties to Goat Milk and Cheese: Obesity, Insulin Resistance, Inflammation and Hepatic Steatosis Prevention. Animals 2021, 11, 2942. https://doi.org/ 10.3390/ani11102942

Academic Editors: José Luis Guzmán-Guerrero, Manuel Delgado-Pertíñez and A. Ignacio Martín-García

Received: 26 July 2021

Accepted: 6 October 2021

Published: 12 October 2021

Publisher's Note: MDPI stays neutral with regard to jurisdictional claims in published maps and institutional affiliations.

Copyright: (c) 2021 by the authors. Licensee MDPI, Basel, Switzerland. This article is an open access article distributed under the terms and conditions of the Creative Commons Attribution (CC BY) license (https:// creativecommons.org/licenses/by/ $4.0 /)$.
Simple Summary: The aim of this study was to review the benefits of producing milk and cheese under grazing/browsing systems on rangelands in terms of bioactivity and the health benefits of their consumption in these animals. Firstly, we looked over at the forages consumed by goats on the rangelands and at the plant's bioactive compounds. Additionally, goat milk and cheese coming from (1) grazing animals, (2) animals managed indoors, and from (3) animals managed indoors, but supplemented with rich plant bioactive compounds, were examined. In the end, milk was analyzed to modulate the negative effects of high-fat diet in mice. The results revealed that grazing/browsing practices are superior to indoor feeding to promote the transference of bioactive compounds from vegetation to animal tissues, and finally to animal products. Grazing/browsing management represents a better option than indoor feeding to enhance the bioactivity of milk and cheese. Supplementation with rich-bioactive compound forages increased total polyphenol, hydroxycinnamic acids, and flavonoid concentrations in both products. The consumption of goat milk prevents obesity, insulin resistance, inflammation, and hepatic steatosis in mice.

Abstract: The rangeland is an ecological resource that provides multiple benefits for environment and agriculture. Grazing/browsing on rangelands is a useful and inexpensive means to produce food derived from animal products. The aim of this study was to review the benefits of producing milk and cheese under this system in terms of bioactivity and the health benefits of their consumption in model animals. To conduct this review, we particularly considered the experiments that our research group carried out along the last fifteen years at the Instituto Nacional de Ciencias Médicas y Nutrición Salvador Zubirán in Mexico. Firstly, we examined the forages consumed by goats on the rangelands in terms of plant bioactive compound occurrence and their concentration. Further, goat milk and cheese coming from (1) grazing animals, (2) animals managed indoors, and from (3) animals managed indoor supplemented with rich plant bioactive compounds, were analyzed. Milk was discussed to modulate the negative effects of high-fat diets in mice. Forages consumed by goats on the rangelands showed a close correlation between antioxidant activity assessed by the $\mathrm{DPPH}^{+}$radical with total flavonoid and total polyphenol contents (TPC). Milk concentration of PUFA, MUFA, and n-3 fatty acids from grazing goats $(4.7 \%, 25.2 \%$, and $0.94 \%$ of FAME) was higher than milk from goats fed indoor diets (ID). Similar results were shown in cheese. TPC was higher in cheese manufactured with milk from grazing goats ( $300 \mathrm{mg}$ of GAE $/ \mathrm{kg}$ of cheese) when compared to cheese from milk goats fed ID (60 mg of GAE/of cheese). Acacia pods are a semiarid rangeland feed resource that transfers prohealthy activity, inhibited in vitro lipid peroxidation (inhibition of TBARS formation) and diminished the damage induced by reactive oxygen species (ROS). Additionally, in vivo assessment revealed that Acacia species increased free radical scavenging (DPPH), oxygen radical absorbance capacity, and anti-inflammatory activity. The results highlight that grazing/browsing practices are superior to indoor feeding in order to promote the transference of bioactive compounds from vegetation 
to animal tissue, and finally to animal products. Grazing management represents a better option than indoor feeding to enhance bioactivity of milk and cheese. Supplementation with rich-bioactive compound forages increased total polyphenol, hydroxycinnamic acids, and flavonoid concentrations in milk and cheese. The consumption of goat milk prevents obesity, insulin resistance, inflammation, and hepatic steatosis while on a high-fat diet induced obesity in mice.

Keywords: bioactive compounds; antioxidant activity; n-3; fatty acids; phenols; healthy foods; phytochemicals

\section{Introduction}

Grazing/browsing is a useful and inexpensive tool to improve the presence of bioactive compounds and by this means increase the bioactivity of milk and cheese [1]. This type of feeding is a sustainable alternative for ruminants' production, if available natural resources and animals' needs are harmonized [2,3]. This means of production is crucial to support food security and to increase household income of smallholders around the world [4]. Highly diverse pastures concentrate a wide range of plant bioactive compounds (PBC) that are better than monoculture or poor-species grasslands [3,5]. Likewise, grazing/browsing practices have proved to be superior over indoor feeding to promote the transference of bioactive compounds from vegetation to animal metabolism and to animal products [6-8]. These effects have been confirmed in different animal species and in distinct food animal products [5,9-11].

Though most goat production systems in developing countries face pitfalls such as poor forage quality, water scarcity, or inconstant feed supply throughout the seasons; such animal farming has the potential to produce dairy products with pro-healthy properties $[2,12]$. Despite the fact that many variables modify the content of bioactive compounds of milk and cheese, it is well accepted that animal feeding is the factor that has the greatest impact $[13,14]$. In addition, indoor feeding has shown benefits in terms of bioactivity if the animal diet includes substantial bioactive ingredients that surpass the animal's biological metabolism and reaches the milk and cheese components [15-18]. Anti-inflammatory, anticarcinogenic, and cardioprotective effects of phytonutrients $[19,20]$ are the most common desirable effects that might be found in milk and cheese [21,22]. This sheds light into why goat milk and cheese have claimed benefits for human nutrition and health [23,24].

In the recent years remarkable advances have been made to understand the impacts of sustainable ruminant farming systems and the benefits to human nutrition and health [25-27]. Different approaches have been taken to identify the compounds involved in such claimed benefits and the likely pathways followed by such compounds to exhibit pro-healthy benefits in food deliveries. In line with this, the bioactive compounds that our research group has reported in goat milk and cheese included poly-unsaturated fatty acids, flavonoids, catechin, hydroxycinnamic acids, phenols, and terpenes, among others. The bioactive compounds ingested by animals coming from plant species and the potential benefits of the compounds later found in dairy deliveries should be fully identified to better understand the metabolic mechanisms to increase their occurrence and their concentration in order to exert such favorable biological functions [12]. Further, this information should have practical application to provide appropriate recommendations regarding the likely effects of their intake by humans. To reach these objectives, it is necessary to investigate goat browsed/grazed vegetation.

To elucidate the potential sources of plant bioactive compounds [28] and to analyze the botanical components to confirm the origin of these phytochemicals [29], analyses were made. Some species or theirs parts exhibited special properties beyond their nutritional value, e.g., Acacia farnesiana $[15,30]$. Some other species performed well as a rich source of anti-inflammatory agents, while also protecting against oxidative-induced damage in biological models e.g., A. farnesiana and A. schaffneri [31]. Our recent findings showed that 
bioactivity of dairy products is enhanced when goats are under browsing/grazing management or supplemented with A. farnesiana pods meal [15]. As well, goat milk ingestion can support antioxidant activity of biological systems and even modulate chronic disease while regulating inflammatory indicators to prevent obesity and related maladies [32].

To our knowledge, there is a gap in the literature regarding the traceability of bioactive compounds consumed by animals on rangelands, their occurrence in goat milk and cheese and the likely benefits to curb maladies as obesity and related disorders in animal models. In the present review, goat milk $[8,15]$ and cheese $[6-8,13]$ were revisited on their bioactive compound content. In addition, in vitro and in vivo assays were considered to have the evidence of the effects of such compounds [30-32]. To conduct this review, we took into account particularly the experiments that our research group carried out throughout the last fifteen years at the Instituto Nacional de Ciencias Médicas y Nutrición Salvador Zubirán (INCMNSZ) in Mexico. The initial works of our research group dealing with botanical screening, nutritive value and sustainability of rangelands started in the late 90 s and the early 00s $[28,33]$ and has continued until recent times [34]. In addition, the grazing/browsing effect on quality of animal products has been a topic of our interest. In this review, we summarized the most meaningful findings of grazing/browsing semiarid rangeland feed resources to increase bioactivity and pro-healthy properties to goat cheese and milk.

We proved that goat milk intake prevents chronical illness in animal models. In this publication, "rangeland" was defined according to Allen et al. [35], as the "land on which indigenous vegetation is predominantly grass, grass-like plants, forbs, or shrubs that are grazed, or have the potential to be grazed, and which is used as a natural ecosystem for the production of grazing livestock". Likewise, secondary metabolite was defined according to Martirosyan et al. [36] as "the molecules in food, usually in small amounts, that act synergistically to benefit health".

\section{Materials and Methods}

\subsection{Experiment 1}

The rangeland used for this experiment was located in Queretaro, Mexico $\left(20^{\circ} 35^{\prime}\right.$ Northern latitude, $100^{\circ} 18^{\prime}$ Western longitude: 1950 m.a.s.l.). The area has a dry, semiarid climate with $460 \mathrm{~mm}$ of average precipitation per year. The vegetation included forbs, leguminous trees and Opuntia species (Table 1). Sampling of grazed/browsed species was performed by hand simulating the mouthful of the goat. The sampling included leaves, stems, fruit or a combination of them, in line with the natural ingestion patterns of goats on the rangelands. Rangeland vegetation species were collected and dried on three different days and sampling was done twice on every observational day $(n=6)$. Analysis of antioxidant activity on vegetation samples was done according to Sharma and Bhat [37]; while total phenol content was determined according to Folin-Ciocalteu colorimetric method described by Taga et al. [38]. Goats had an average weight of $50 \pm 5 \mathrm{~kg}$ and a lactation period of 150 days. Two animal groups were set up with French Alpine goats. (1) The grazing group fed exclusively local vegetation species available in the rangeland area. (2) Indoor feeding management consisted of grain concentrate (rolled corn $55 \%$, wheat bran $17 \%$, barley $15 \%$, soybean $9.3 \%$, and vitamins and minerals $3.7 \%$ ) supplemented with Lucerne hay. Both animal groups were managed with overnight confinement. The grazing group did not receive any additional feed supply. Goats were milked daily at 7:00 a.m. Milk from each replicate group of five animals each (two replicate groups per treatment were selected) was collected during five consecutive days. Further, soft artisan cheese was manufactured and analyzed [8]. Total milk fat was determined according to Folch et al. [39]. Further, lipids were dissolved in hexane and sodium hydroxide methanol solutions for saponification. Later, transesterification of milk fat to methyl esters were done following the recommendations of the official method 696.33, AOAC [40]. Finally, fatty acid methyl esters (FAME) were quantified by gas chromatography [8]. 
Table 1. Antioxidant activity and total polyphenol content of vegetation species browsed/grazed by goats on semiarid rangelands (modified and adapted from Cuchillo et al., 2013 [29]). $\mathrm{n}=6$.

\begin{tabular}{|c|c|c|c|}
\hline Specie & Portion & $\begin{array}{l}\text { Antioxidant Activity } \\
\text { (AA, \%) }\end{array}$ & $\begin{array}{c}\text { Total Polyphenol Content (TPC) } \\
\text { (mg of Gallic Acid Equivalents/kg DM) }\end{array}$ \\
\hline Aristida adscensionis & Complete & $24.34^{g}$ & $160^{1, m}$ \\
\hline Acacia schaffneri & Complete $^{1}$ & $47.38^{a}$ & $2730^{b}$ \\
\hline Bouteloua curtipendula & Complete & $35.42^{d}$ & $314 \mathrm{~g}, \mathrm{~h}, \mathrm{i}$ \\
\hline Bouteloua repens & Complete & $30.92^{b, c}$ & $364^{g}$ \\
\hline Chloris virgata & Complete & $27.39^{\mathrm{i}}$ & $474^{\mathrm{f}}$ \\
\hline Jatropha dioica & Complete & $24.13^{g}$ & $1891^{k}$ \\
\hline Leptochloa dubia & Complete & $21.48^{\mathrm{h}}$ & $146^{1, m, n}$ \\
\hline Mimosa biuncifera & Complete & $28.70^{e, f}$ & $341^{\mathrm{g}, \mathrm{h}}$ \\
\hline Rhynchelytrum roseum & Complete & $44.63^{\mathrm{b}, \mathrm{c}}$ & $23^{i, j, k}$ \\
\hline Urochloa fasciculata & Complete & $30.19^{\mathrm{e}}$ & $966^{c}$ \\
\hline Mean value & & $31.46^{\mathrm{A} *}$ & $592 \mathrm{~A} *$ \\
\hline Acacia farnesiana & Fruits & $47.59^{a}$ & $38170^{a}$ \\
\hline Opuntia amyctaea & Fruits & $20.83^{h}$ & $587^{\mathrm{e}}$ \\
\hline Opuntia hytiacantha & Fruits & $18.30^{\mathrm{i}}$ & $343^{g, h}$ \\
\hline Prosopis laevigata & Fruits & $22.92^{g, h}$ & $314^{\mathrm{g}, \mathrm{h}}$ \\
\hline Mean value & & $27.41^{\mathrm{B} *}$ & $9854^{\mathrm{B} * *}$ \\
\hline Celtis pallida & Leaves & 29.49 e,f & $280^{h, i, j}$ \\
\hline Prosopis laevigata & Leaves & $35.68^{\mathrm{d}}$ & $968^{c}$ \\
\hline Verbesina serrata & Leaves & $17.04^{\mathrm{i}}$ & $272^{i, j}$ \\
\hline Mean value & & $27.40^{\mathrm{B} *}$ & $507^{C} * *$ \\
\hline Celtis pallida & Stems & $44.02^{c}$ & $370 \mathrm{~g}$ \\
\hline Verbesina serrata & Stems & $17.78^{\mathrm{i}}$ & $874^{\mathrm{d}}$ \\
\hline Zalazania augusta & Stems & $46.41^{\mathrm{a}, \mathrm{b}}$ & $480^{\mathrm{f}}$ \\
\hline Mean value & & $36.07^{A} *$ & $575^{\mathrm{D} *}$ \\
\hline Opuntia affasiacantha & Cladodes & $24.13^{g}$ & $202^{k}$ \\
\hline Opuntia hytiacantha & Cladodes & $46.92^{\mathrm{a}}$ & $77^{n}$ \\
\hline Opuntia robusta & Cladodes & $16.14^{\mathrm{i}}$ & $537^{\mathrm{e}, \mathrm{f}}$ \\
\hline Opuntia streptacantha & Cladodes & $16.39^{\mathrm{i}}$ & $147^{\mathrm{l}, \mathrm{m}, \mathrm{n}}$ \\
\hline Opuntia tomentosa & Cladodes & $16.77^{\mathrm{i}}$ & $335 \mathrm{~g}, \mathrm{~h}, \mathrm{i}$ \\
\hline Mean value & & $24.07^{B, C} * *$ & $259^{\mathrm{E} *}$ \\
\hline
\end{tabular}

Complete $=$ mixture of leaves and stems $;^{1}=$ mix of leaves, stems, and pods. DPPH ${ }^{+}=1,1$-diphenyl-2-picrylhydrazyl $(2 \mathrm{mg}$ of DPPH+ in $100 \mathrm{~mL}$ of methanol). ${ }^{a, b, c, d, e, f, g, h, i, j, k, l, m, n}$ Means with different letters within columns are significantly different at alfa $=0.05$. Means with capital letters are significantly different $(* p=0.05$; ** $p=0.001$ ) within the column, where: $\mathrm{A} \neq \mathrm{B} * *, \mathrm{~A} \neq \mathrm{D} * \mathrm{~B} \neq \mathrm{C} * *$, and $\mathrm{D} \neq \mathrm{E} *$.

\subsection{Experiment 2}

For the second experiment, French Alpine goats $(50 \pm 5 \mathrm{~kg})$ were selected and a lactation period of 150 days were allocated into three groups, as follows: (1) grazing/browsing goats; (2) conventional diet (CD); and (3) conventional diet supplemented with $30 \%$ of Acacia farnesiana pods meal (AF). Goats were housed in herds of ten animals each. Grazing animals were allowed to graze/browse during $8 \mathrm{~h} / \mathrm{d}$ on 14 ha of shrubby rangeland after milking with overnight confinement. Animals fed conventional diet or supplemented conventional diet were kept in full confinement along the experiment. Feedstuffs for indoor feeding was harvested (Lucerne hay) and prepared (grain concentrate) once for the complete experimental period and stored separately. The proportion used was $60 / 40$ (Lucerne hay/grain concentrate) for indoor feeding; while 42/28/30 (Lucerne hay /grain concentrate/A. farnesiana pods meal) proportion was used in the supplemented diet. Milk samples of each animal group were collected separately in seven consecutive days following the adaptation period of 12 days [15]. Fatty acid profile determination was performed the first experiment. Total phenolic content was determined by the Folin-Ciocalteu colorimetric [41] with some modifications described by Puga et al. [15]. Antioxidant activity of 
milk was carried out according to Koren et al. [42]. Flavonoids and phenolic acids were determined by HPLC [15].

\subsection{Experiment 3}

French Alpine with Saanen and Toggenburg crossbred-goats (120 goats) were allowed to pasture 14 ha of shrub land per day. The average weight of the adult females was $55 \pm 5 \mathrm{~kg}$, and they were in mid-lactation. The management of the goats included daily grazing on the rangeland after milking with overnight confinement. Sixty goats were kept indoors in full confinement during the study. Milk from each group of goats was pooled and artisan cheese was manufactured [6]. Fatty acid profile determination was performed as Experiments 1 and 2. Total phenolic content was determined by the FolinCiocalteu colorimetric test [41] with some modifications described by Puga et al. [15]. Antioxidant activity of milk was carried out according to Koren et al. [42]. Mono and sesquiterpenes volatile compounds were analyzed by Purge and Trap Dynamic Head Space technique and separated by gas chromatography. Further, terpenes were identified by mass spectrometry [6].

\subsection{Experiment 4}

Two groups of 40 French Alpine goats that weighed $50 \pm 5 \mathrm{~kg}$ was arranged. All animals had 70 to 80 milking days. Grazing group grazed/pastured $8 \mathrm{~h} / \mathrm{d}$ on 14 ha of natural rangeland with overnight confinement supplemented with $200 \mathrm{~g}$ of concentrate grain $(18 \% \mathrm{CP})$ in the morning and $300 \mathrm{~g}$ Lucerne hay in the evening. The indoor group was kept in full confinement during the study, fed $1 \mathrm{~kg}(18 \%$ of CP and $2.5 \mathrm{Mcal} / \mathrm{kg})$ of grain concentrate supplemented with $1.5 \mathrm{~kg}$ Lucerne hay/day. The goats were milked once daily at 7:00 $\mathrm{h}$ along five days. Soft artisan cheese was manufactured and analyzed [13]. Fatty acid profile determination was performed for Experiments 1, 2, and 3.

\subsection{Experiment 5}

This experiment used the same animals and conditions of Experiment 1, but instead of evaluating goat milk, this experiment was designed to assess soft goat cheese [8]. In addition, complementary parameters such as antioxidant activity and bioactive compounds were analyzed to better characterize goat cheese [7]. Determination of fatty acid profile and total phenolic content was determined as Experiment 2 [15]. Antioxidant activity was calculated with the methodology of Hatano et al. [43], while flavonoids and hydroxycinnamic acids were measured by HPLC [7].

\subsection{Experiment 6}

In this experiment, two assays were performed to determine the antioxidant activity and protection against oxidative induced damage of crude extracts of Acacia farnesiana and A. schaffneri pods. It is important to remember that both plant species are rich sources of phytochemicals and are important components of goat diet in browsing/grazing rangeland management. Firstly, the protective effect of crude extracts of Acacia pods were challenged against $\mathrm{H}_{2} \mathrm{O}_{2}$ using pig kidney LLC-PK1 cells in an in vitro assay. Secondly, gerbils (Meriones unguiculatus) were employed (in vivo assay) to observe the effect of crude extract of Acacia pods on plasma antioxidant capacity [31]. Free radical scavenging capacity of A. schaffneri and A. farnesiana was carried out using the decoloration reduction of ABTS•+ assay from Re et al. [44], while $\mathrm{DPPH}^{+}$assay was performed according to Von Gadow et al. [45], and liposomes measured according to Tsuda et al. [46]. To evaluate antioxidant activity in pig kidney cells LLC-PK1 line cells were employed as Hernández-Fonseca et al. recommended [47]. DPPH ${ }^{+}$scavenging capacity in gerbil plasma was determined according to Koren et al. [42], while oxygen radical absorbance capacity (ORAC) assays were based on the method described by Huang et al. [48]. 


\subsection{Experiment 7}

To follow up with the characterization of goat feeds from semiarid rangelands as valuable resources of bioactive compound source; five organic extracts (chloroformic, hexanic, ketonic, methanolic, methanolic:aqueous, and one aqueous extract) of $A$. farnesiana pods were tested in vitro and in vivo. All extracts were challenged to investigate their antioxidant activity and protection against oxidative-induced damage as well as their capacity to curb the inflammation process and to downregulate the pro-inflammatory mediators [30]. Total phenolic content was determined by the Folin-Ciocalteu colorimetric method described by Singleton et al. [49]. To evaluate the quantitative antioxidant activity, DPPH• (2,2-diphenyl-1-picrylhydrazyl) reagent was employed according to Koren et al. [42]. For the in vivo model, eight groups of mice with six animals each were employed. Ear edema (weight, and thickness ear) essay in CD-1 mice induced with 12-o-tetradecanoylphorbol acetate (TPA), oxidative enzyme myeloperoxidase assay (MPO), histological analysis of ear, immunohistochemistry, quantitation of IL-1 $\beta$, IL-6, and tumor necrosis factor alpha (TNF- $\alpha$ ) tests were done according to Del-Ángel et al. [50] and Delgadillo et al. [51].

\subsection{Experiment 8}

In this experiment, the effect of (1) milk from goats fed a conventional diet, (2) milk from conventional diet supplemented by $30 \%$ A. farnesiana pods and (3) milk from grazing goats on metabolic alterations in mice fed a high fat diet was evaluated. Male C57BL/ 6 mice were housed in micro-isolator cages. These animals were randomly assigned into five groups $(\mathrm{n}=6)$ receiving the following diets: (1) control; (2) high-fat $(\mathrm{HF}) ;(3) \mathrm{HF}+$ dry milk from goats fed a conventional diet (HFCD); (4) HF + dry milk from goats fed on grazing (HFG); and (5) HF + dry milk from goats fed a conventional diet supplemented with $30 \%$ of $A$. farnesiana pods. Body weight, body composition (percentage of fat and lean mass), energy expenditure measurement, intraperitoneal glucose, insulin tolerance test, histological analysis of liver, pancreas, white and brown adipose tissue, mitochondria abundance, and lipid content in skeletal muscle and liver were evaluated. Likewise, immunoblotting and immunohistochemistry in BAT of UCP-1, and TNF- $\alpha$ quantitation in adipose tissue were evaluated. Further details of the employed methodology can be found in our previous paper [32].

\subsection{Statistical Analyses}

Total polyphenol content and quantitative radical scavenging activity of plant samples were analysed by ANOVA $(p=0.05)$ using SAS (SAS Institute Inc, Cary, NC, USA) [52]. The days of collection were treated as repeated measurements. For each plant portion (complete fruits, leaves and stems; cladodes for Opuntia species) we used the nonparametric statistic of $\mathrm{K}$ independent samples. The Kruskal-Wallis test was used to establish differences among plant portions. Further, the Mann-Whitney U signed ranks test for related pairs of portions was used to identify such differences [53]. In vivo effects on bioactivity and healthy properties against induced obesity were evaluated by one-way ANOVA, followed by Tukey multiple comparison post hoc test using GraphPad Prism 7.0 (GraphPad Software, San Diego, CA, USA). The differences were considered statistically significant at $p<0.05$.

\section{Results}

3.1. Antioxidant Activity and Total Polyphenol Content of Vegetation Species Browsed/Grazed by Goats on Semiarid Rangelands

For the analysis of antioxidant activity of rangeland vegetation, complete plants yielded the best anti-free-radical performance, followed by fruits (including pods), stems, and leaves, respectively (Table 1). Our results revealed a close Pearson's correlation of the antioxidant activity assessed by the $\mathrm{DPPH}^{+}$radical with total flavonoid $(\mathrm{r}=0.869$; Figure 1a) and total polyphenol content (TPC; $r=0.945$; Figure $1 b$ ). In addition, fruits from rangeland vegetation species had the highest mean value for TPC, while cladodes had the lowest $(p<0.001)$. In line with this outcome, the same association was observed when stems 
and cladodes were contrasted $(p<0.001)$. However, when individual species were analyzed, A. farnesiana pods showed the largest TPC (38,170 mg of gallic acid equivalents $/ \mathrm{kg} \mathrm{DM})$ value, followed by $A$. schaffneri ( $2730 \mathrm{mg}$ of gallic acid equivalents $/ \mathrm{kg} \mathrm{MD}$ ). This remarkable TPC associated with the antioxidant activity parameter were the reasons to utilize both feed resources in the following experiments to better know the extent of their utilization in goat feeding and the likely changes in bioactivity and pro-health properties of milk and cheese.
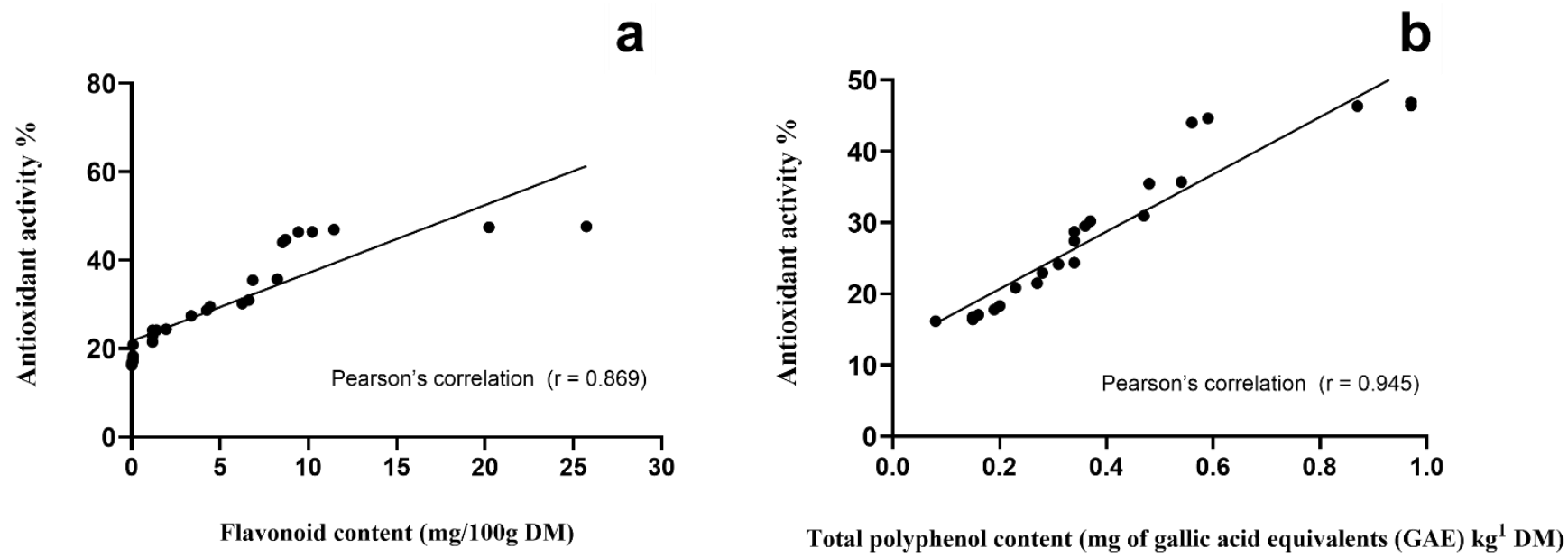

Figure 1. Pearson's correlations of flavonoid (a) and total polyphenol (b) content versus antioxidant activity of vegetation species browsed/grazed by goats on semiarid rangelands.

\subsection{Bioactive Compounds in Goas Milk and Cheese}

\subsubsection{Fatty Acids in Goat's Milk and Cheese}

In Experiment 1 (Table 2), the largest concentration of polyunsaturated fatty acids (PUFA) and monounsaturated fatty acids (MUFA) was found in milk coming from grazing goats ( $4.7 \%$ and $25.2 \%$ of fatty acid methyl esters-FAME), followed by milk from goats fed conventional diets ( $3.4 \%$ and $19.9 \%$ of FAME). In the same line, $\mathrm{n}-3$ fatty acids concentration in milk from grazing goats was superior to indoor diets ( $0.94 \%$ vs. $0.72 \%$, respectively). However, the maximum saturated fatty acids (SFA) mean value was obtained in milk from goats fed conventional diets (70.3\% of FAME) in comparison to grazing management $(64.4 \%)$. In contrast to Experiment 1; in Experiment 2 we found that milk from indoor depicted with the top value of PUFA (5.6\%), MUFA (31.6\%) and n-3 fatty acids (0.96\%) content. On the other hand, grazing treatment and indoor group supplemented with $30 \%$ of A. farnesiana (AF) pods increased the content of SFA of goat milk $(69.7 \%$ and $69.4 \%$ of FAME, respectively) in relation to conventional diet, conventional diet plus $10 \%$ of AF and conventional diet plus $20 \%$ of $\mathrm{AF}(62.7 \%, 62.8 \%$, and $62.8 \%$ of FAME, respectively). Moreover, conjugated linoleic acid (CLA) was found in higher proportion in grazing treatment $(0.29 \%$; versus the rest of the treatments which average $0.22 \%$ of FAME).

In line with Experiment 1; Experiment 3 showed that grazing management increases PUFA and MUFA (6.1\% and 23.5\%) fatty acids share of cheese in relation to indoor feeding $(5.2 \%$ and $23.8 \%)$. Likewise, the SFA was found lower for grazing system $(68.9 \%)$ and higher for cheese from indoor diet $(69.4 \%)$. For the total concentration of n-3 fatty acids, no differences were detected. In Experiment 4, the results indicated that PUFA were higher in cheese made with goat milk from indoor diet $(5.1 \%)$ in relation to grazing feeding $(3.9 \%)$. For the total concentration of $n-3$ series we observed no differences. However, the total concentration of n-6 fatty acids in cheese from goats fed indoor diet was higher when compared to the cheese elaborated with milk from grazing goats. Therefore, at the end, the n-3:n-6 ratio was more advantageous for grazing system ( 0.36 vs. 0.26$)$. In the case of Experiment 5, grazing management decreased PUFA content (4.8\%) in relation to indoor 
management (5.4\%). However, MUFA value was superior in cheese made with milk from grazing goats $(25.3 \%)$ over the cheese coming from goats fed a conventional diet $(23.9 \%)$.

Table 2. Bioactivity and pro-health properties of milk (Experiments 1 and 2) and cheese (Experiments 3, 4, and 5) made with milk coming from goats either grazing/browsing semiarid rangeland or fed indoor diets (modified and adapted from Cuchillo et al. [8]; Cuchillo et al. [7]; Puga et al. [15]; Galina et al. [6] and Puga et al. [13]).

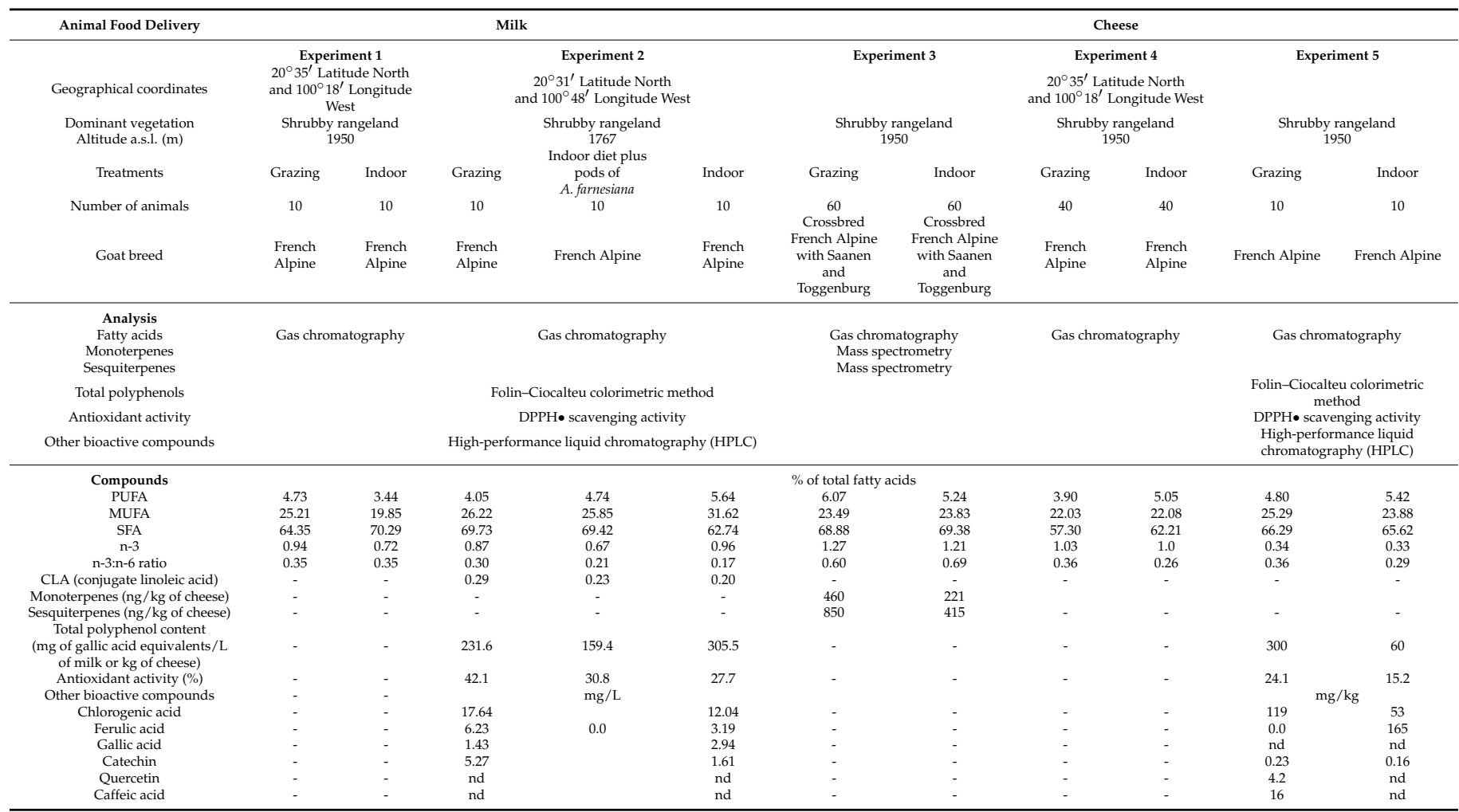

PUFA $=$ polyunsaturated fatty acids; MUFA $=$ monounsaturated fatty acids. SFA $=$ saturated fatty acids. CLA = conjugated linoleic acid isomers (cis-9, trans-11; trans-9, cis-11; trans-10, cis-12, cis-10, cis-12). DPPH $\bullet=2,2$-diphenyl-1-picrylhydrazyl; nd = not detected.3.3. Antioxidant and anti-inflammatory activity of acacia pods extracts.

3.2.2. Phenolic Content, Flavonoids, Terpenes, Hydroxycinnamic Acids, and Antioxidant Activity in Goat's Milk and Cheese

Apart from the fatty acid profile, the inclusion of AF pods in the goat's diets improved the total phenolic content in the milk (Experiment 2) significantly. The highest concentration of total phenols was found in the indoor diet supplemented with AF (305.5 mg of gallic acid equivalents-GAE/L of milk), while indoor diet, i.e., indoor diet without supplementation was the lowest in this respect (159.4 $\mathrm{mg}$ of GAE/L of milk). The grazing system also increased this parameter, but at a lesser extent than indoor diet plus AF supplementation (231.6 mg of GAE/L of milk). It is important to notice that gallic, chlorogenic, and ferulic acids were detected in all analyzed milk except in that milk from indoor management. This effect was also observed for catechin, which was not identified in milk from conventional indoor diet. AF pods in addition to indoor diet encouraged the concentration of phenolic compounds and catechin in goat milk. Nevertheless, the greatest value of those bioactive compounds was found in the milk coming from goats in the grazing system. Additionally, milk from animals that grazed/browsed had the best performance (42.1\%) to scavenge free radicals in relation to indoor $(27.7 \%)$ and indoor diet supplemented with AF (30.8\%). In addition, a positive correlation was found between the antioxidant activity and the bioactive compound concentrations. In the case of Experiment 5, the total polyphenol content was higher in cheese manufactured with milk from grazing goats (300 mg of GAE/kg of cheese) versus cheese made with milk from goats fed an indoor diet (60 mg of GAE/of cheese). Antioxidant activity followed the same pattern, i.e., cheese from grazing management 
(24.1\%) was superior in comparison to indoor cheese (15.2\%). Likewise, caffeic acid was detected exclusively in cheese made with milk from animals under grazing feeding. Interestingly, indoor cheeses reported higher mean values of ferulic acid than grazing cheese (24.1 versus $15.2 \%$ ). Experiment 3 showed that monoterpene and sesquiterpene contents in goat cheese were superior in grazing management (460 and $850 \mathrm{ng} / \mathrm{kg}$ cheese) to indoor feeding (221 and $415 \mathrm{ng} / \mathrm{kg}$ cheese), respectively.

In Experiment 6, Acacia pods extracts were evaluated for total phenol content (TPC), antioxidant and anti-inflammatory activity in vitro and in vivo as shown in Table 3. TPC ranged from 76 to $620 \mathrm{mg}$ equivalent of gallic acid per gram of extract or $100 \mathrm{~g}$ of pods dry matter. In the case of radical scavenging activity of A. shaffneri (AS) and A. farnesiana (AF) pods extract ranged from $79 \%$ to $95 \%$. In the same experiment, with the decolorization reduction of ABTS ${ }^{+}$assay, we observed the same performance of the two Acacia species (10\% of reduction). Lipid peroxidation was inhibited (inhibition of TBARS formation) to the same extent by both Acacia species (66\%). However, when we evaluated the different extracts, contrasting reduction parameters were observed, ranging from $4 \%$ to $17 \%$. AS and $\mathrm{AF}$ were able to inhibit the damage induced by reactive oxygen species (ROS). In the same line, oxygen radical absorbance capacity and ferric-reducing antioxidant power showed divergent results, e.g., data registered for ME (450 and 2.0) and MEAE (500 and 1.7). AS and AF extracts evaluated in gerbil plasma proved its positive effects on free radical scavenging (DPPH) and oxygen radical absorbance capacity. In relation to anti-inflammatory activity, AF pod extracts showed important effects on CD-1 mice with induced damage; i.e., all extracts reduced edema and ear thickness induced by TPA (12-O-tetradecanoylphorbol-3acetate). Additionally, the presence of inflammatory interleukins (Il-1 $\beta$, Il- 6 , and TNF- $\alpha$ ) was curbed with the use of Acacia pod extracts.

Table 3. Goat feeds as bioactive compounds sources: in vitro and in vivo effects on bioactivity and pro-health properties (modified and adapted from and Puga et al. [30] and Delgadillo et al. [31]).

\begin{tabular}{|c|c|c|c|c|c|c|c|c|}
\hline & \multicolumn{2}{|c|}{ Experiment 6} & \multicolumn{6}{|c|}{ Experiment 7} \\
\hline & & & \multicolumn{6}{|c|}{ In Vitro } \\
\hline \multirow{2}{*}{ Variables } & \multirow{2}{*}{ AS } & \multirow{2}{*}{ AF } & \multicolumn{6}{|c|}{ Acacia farnesiana Pods Extracts } \\
\hline & & & CE & HE & KE & ME & MEAE & $\mathrm{AE}$ \\
\hline \multirow{2}{*}{$\begin{array}{c}\text { Total polyphenol (TP) } \\
\text { mg of equivalent of gallic acid/g of } \\
\text { extract }\end{array}$} & \multirow{2}{*}{$213^{\mathrm{a}}$} & \multirow{2}{*}{$76^{\mathrm{b}}$} & \multicolumn{6}{|c|}{ TPC, mg of equivalent of gallic acid/100 g pods, dry matter } \\
\hline & & & $506^{c}$ & $620^{a}$ & $594^{b}$ & $378^{d}$ & $399^{d}$ & $565^{b}$ \\
\hline $\begin{array}{l}\text { Free radical scavenging capacity \% } \\
\left(\mathrm{DPPH}^{+}\right)\end{array}$ & $95^{\mathrm{a}}$ & $95^{\mathrm{a}}$ & $90^{\mathrm{a}}$ & $80^{\mathrm{b}}$ & $79^{\mathrm{b}}$ & $82^{\mathrm{b}}$ & $80^{\mathrm{b}}$ & $80^{\mathrm{b}}$ \\
\hline $\begin{array}{l}\text { Free radical scavenging capacity \% } \\
\qquad\left(\mathrm{ABTS}^{+}\right)\end{array}$ & $10^{\mathrm{a}}$ & $10^{\mathrm{a}}$ & - & - & - & - & - & - \\
\hline \multirow{2}{*}{ Inhibition of TBARS formation, $\%$} & \multirow{2}{*}{$66^{\mathrm{a}}$} & \multirow{2}{*}{$66^{\mathrm{a}}$} & \multicolumn{6}{|c|}{$\mathrm{IC}_{50}$ on TBARS ug $/ \mathrm{mL}$} \\
\hline & & & $9^{b}$ & $12^{\mathrm{a}}$ & $4.0^{c}$ & $4.5^{c}$ & $4.5^{c}$ & $17^{a}$ \\
\hline $\begin{array}{c}\text { Protection against } \mathrm{H}_{2} \mathrm{O}_{2} \\
\text { oxidative-induced damage }{ }^{+} ;(\%)\end{array}$ & ++ & +++ & $37^{\mathrm{a}}$ & $25^{b}$ & $36^{a}$ & $18^{c}$ & $23^{b}$ & $18^{c}$ \\
\hline $\begin{array}{l}\text { Oxygen radical absorbance capacity, } \\
\text { (ORAC) } \S\end{array}$ & - & - & $150^{c}$ & $100^{d}$ & $450^{\mathrm{b}}$ & $450^{\mathrm{b}}$ & $500^{\mathrm{a}}$ & $50^{\mathrm{e}}$ \\
\hline $\begin{array}{l}\text { Ferric-reducing antioxidant power } \\
\qquad(\text { FRAP) }\end{array}$ & - & - & $1.5^{\mathrm{a}}$ & $1.4^{\mathrm{a}}$ & $1.5^{\mathrm{a}}$ & $2.0^{\mathrm{a}}$ & $1.7^{\mathrm{a}}$ & $1.4^{\mathrm{a}}$ \\
\hline
\end{tabular}


Table 3. Cont.

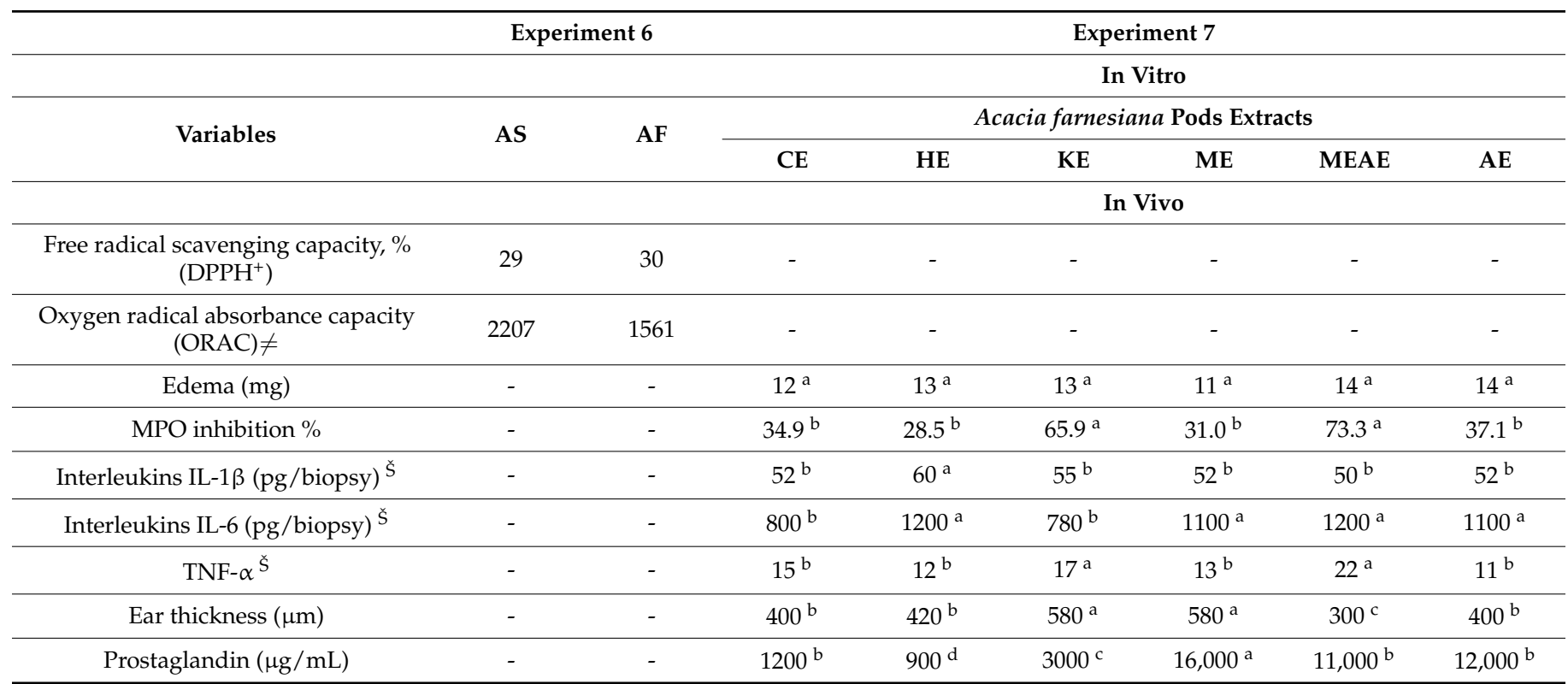

$\mathrm{AS}=$ Acacia schaffneri; $\mathrm{AF}=$ Acacia farnesiana; $\mathrm{DPPH}^{+}=1,1$-diphenyl-2-picrylhydrazyl; $\mathrm{ABTS}=2,2^{\prime}$-azino-bis (3-ethylbenzthiazoline-6sulphonic acid); TBARS = thiobarbituric acid reactive substances; ORAC = oxygen radical absorbance capacity; FRAP = ferric reducing antioxidant power. ${ }^{\dagger}$ Extract crude added at $200 \mathrm{ppm} .{ }^{\S} \mu \mathrm{m}$ of Trolox equivalents $/ \mathrm{g}$ of extract. ${ }^{\S} \mathrm{mmol}$ of Trolox equivalents $/ \mathrm{mL}$ of extract. $\neq$ Oxygen radical absorbance capacity $(\mathrm{ORAC})(\mu \mathrm{M}$ Trolox equivalents $/ \mathrm{L})$ of gerbil (Meriones unguiculatus) plasma. $\mathrm{MPO}=$ oxidative enzyme myeloperoxidase. OD = optic density. Interleukins IL-1ß (pg/biopsy). ${ }^{\breve{S}}$ Interleukin in supernatants of homogenates from CD-1 mice ears after treatment with different extracts from $\mathrm{AF}$ pods. $\mathrm{CE}=$ chloroformic extract. $\mathrm{HE}=$ hexanic extract. $\mathrm{KE}=$ ketonic extract. $\mathrm{ME}=$ methanolic extract. $\mathrm{MEAE}=$ methanolic:aqueous extract. $\mathrm{AE}=$ aqueous extract. $\mathrm{CD}=$ goat's milk from conventional diet. $\mathrm{G}=$ goat's milk from grazing diet. $\mathrm{CD}+\mathrm{AF}=$ goat's milk from conventional diet $+30 \%$ of Acacia farnesiana pods flour diet. ${ }^{\mathrm{a}, \mathrm{b}, \mathrm{c}, \mathrm{d}, \mathrm{e}}$ Means with different letters within rows are significantly different at $\alpha=0.05$.

\subsection{In Vivo Prevention of Obesity, Hepatic Steatosis and Insulin Resistance}

In Table 4, we describe the results regarding obesity prevention, hepatic steatosis and insulin resistance in mice fed a high-fat diet (HFD) by the intake of goat milk. We observed a reduction on inflammatory markers, an increase of energy expenditure, and higher presence of mitochondrial content in skeletal muscle in mice fed HFD. Our results show that goat milk intake prevents obesity, reduces fat mass, and increases lean mass in the mice fed with HFD. An increase energy expenditure reflected an important intake average of oxygen consumption $\left(\mathrm{VO}_{2}\right)$, which provides an efficient defense against obesity and its relatedmetabolic diseases as insulin resistance. The latter metabolic abnormality was prevented when the serum insulin in fasting is low, and intraperitoneal glucose tolerance test (ipGTT) reflected a downregulation. Additionally, the size of pancreatic islets was reduced when mice were fed goat milk. HFD feeding caused mitochondria damage function. We also confirmed the ability of goat milk intake to improve mitochondrial function as the results of succinate dehydrogenase (SDH) show activity on the skeletal muscle. Hepatic steatosis appeared as a consequence of overweight. Goat milk effectively prevented hepatic steatosis reducing lipid deposition by quantification of oil red $\mathrm{O}$ staining and $\mathrm{p}$-AMPK/AMPK (Phospho-AMPK/AMPK adenine monophosphate (AMP) activated protein kinase) ratio. Goat milk intake protected brown adipose tissue (BAT) from HFD-induced damage. In the same line, BAT expressed UCP-1 protein activity, which plays a key role in the maintenance of body temperature through transforming the energy produced by glucose and fatty acids in mitochondria into heat. Densitometric analysis of phospho-c-Jun N-terminal kinase JNK/JNK ratio in hepatic tissue was reduced by being fed goat milk. Fatty acid bioactive compounds (eicosapentaenoic acid + docosahexaenoic acid)/arachidonic acid ratio) content in hepatic tissue were found in mice fed with goat milk. 
Table 4. Goat milk used as bioactive compounds source: in vivo effects on bioactivity and pro-healthy properties against induced obesity (modified and adapted from Delgadillo-Puga et al. [32]).

\begin{tabular}{|c|c|c|c|c|c|}
\hline \multirow[b]{2}{*}{ Variables } & \multicolumn{5}{|c|}{ Experiment 8} \\
\hline & Control & HFD & CD & G & $\mathrm{CD}+\mathrm{AF}$ \\
\hline & \multicolumn{5}{|c|}{ Energy intake and body changes } \\
\hline Final body weight $(\mathrm{g})$ & $30^{b}$ & $42^{\mathrm{a}}$ & $29.2^{b}$ & $34.5^{b}$ & $33.8^{\mathrm{b}}$ \\
\hline Body weight gain $(\mathrm{g})$ & $9.5^{c}$ & $21.6^{\mathrm{a}}$ & $9.6^{c}$ & $16.0^{\mathrm{a}, \mathrm{b}}$ & $11.8^{\mathrm{b}, \mathrm{c}}$ \\
\hline Food intake (g/day) & $3.2^{\mathrm{a}, \mathrm{b}}$ & $3^{d}$ & $3.7^{c}$ & $4.4^{\mathrm{a}}$ & $3.9^{\mathrm{b}}$ \\
\hline Energy intake (kcal/day) & $16.1^{\mathrm{c}}$ & $16^{\mathrm{c}}$ & $18.5^{\mathrm{b}}$ & $21.7^{\mathrm{a}}$ & $18.9^{\mathrm{b}}$ \\
\hline Mice body composition Fat mass (\%) & $20^{\mathrm{b}}$ & $35^{\mathrm{a}}$ & $10.5^{\mathrm{c}}$ & $19.5^{\mathrm{b}, \mathrm{c}}$ & $19.1^{b}$ \\
\hline Mice body composition Lean mass (\%) & $75^{b}$ & $62^{c}$ & $86.0^{\mathrm{a}}$ & $78.5^{\mathrm{a}, \mathrm{b}}$ & $77.7^{\mathrm{d}}$ \\
\hline & \multicolumn{5}{|c|}{ Serum and insulin resistance related-parameters } \\
\hline Serum glucose (mg/dL) & $200^{\mathrm{b}}$ & $310^{\mathrm{a}}$ & $228^{b}$ & $263^{a, b}$ & $242^{a, b}$ \\
\hline Serum insulin $(\mathrm{ng} / \mathrm{mL})+$ & $1^{\text {a.b }}$ & $2.8^{\mathrm{a}}$ & $0.63^{b}$ & $0.65^{b}$ & $0.70^{\mathrm{b}}$ \\
\hline ipGTT AUC & $25,000^{b}$ & $45,000^{\mathrm{a}}$ & $19,584^{\mathrm{b}}$ & $28,415^{\mathrm{b}}$ & $22,689^{b}$ \\
\hline ipITT AUC & $13,240 \mathrm{a}, \mathrm{b}$ & $20,000^{a}$ & $14,599 \mathrm{a}, \mathrm{b}$ & $13,240^{a, b}$ & $1741^{\mathrm{b}}$ \\
\hline Pancreatic islets size $\left(\mu \mathrm{m}^{2}\right)$ & $9800^{\mathrm{b}}$ & $20,000^{\mathrm{a}}$ & $8508^{\mathrm{b}}$ & $10,110^{a, b}$ & $6683^{\mathrm{b}}$ \\
\hline & \multicolumn{5}{|c|}{ Energy expenditure and thermogenic changes } \\
\hline $\begin{array}{l}\text { Average } \mathrm{VO}_{2} \text { (oxygen consumption; } \mathrm{mL} / \mathrm{kg} / \mathrm{h} \text { ) } \\
\text { feeding }\end{array}$ & $5700^{b}$ & $5450^{c}$ & $6035.1^{\mathrm{a}}$ & $6059^{a}$ & $5989^{\text {a }}$ \\
\hline $\begin{array}{l}\text { Lipid content BODIPY staining in skeletal muscle } \\
\text { (relative units) }\end{array}$ & $50^{\mathrm{b}}$ & $150^{\mathrm{a}}$ & $38.5^{b}$ & $24.33^{\mathrm{b}}$ & $16.57^{b}$ \\
\hline $\begin{array}{l}\text { Mitochondrial activity SDH staining in skeletal } \\
\text { muscle (relative units) }\end{array}$ & $1900^{\mathrm{b}}$ & $900^{c}$ & $2237 \mathrm{a}, \mathrm{b}$ & $2612^{a}$ & $3075.0^{\mathrm{a}}$ \\
\hline $\begin{array}{l}\text { UCP-1/GAPDH immunoblotting BAT (relative } \\
\text { units) }\end{array}$ & $1^{\mathrm{c}}$ & $1.5^{\mathrm{b}}$ & $1.5^{\mathrm{b}}$ & $2.0^{\mathrm{a}}$ & $2.0^{\mathrm{a}}$ \\
\hline & \multicolumn{5}{|c|}{ Hepatic energy improvement and anti-inflammatory prevention } \\
\hline $\begin{array}{l}\text { Lipid content ORO staining in hepatic tissue } \\
\text { (relative units) }\end{array}$ & $105.8^{b}$ & $300^{\mathrm{a}}$ & $105^{b}$ & $93.48^{\mathrm{b}}$ & $104.4^{\mathrm{b}}$ \\
\hline $\begin{array}{l}\text { p-AMPK/AMPK ratio in hepatic tissue (relative } \\
\text { units) by immunoblotting }\end{array}$ & $1^{\mathrm{c}}$ & $1.0^{\mathrm{c}}$ & $1.41^{\mathrm{b}, \mathrm{c}}$ & $1.82^{b}$ & $2.59^{a}$ \\
\hline $\begin{array}{l}\mathrm{p}-\mathrm{JNK} / \mathrm{JNK} \text { ration in hepatic tissue (relative units) } \\
\text { by immunoblotting }\end{array}$ & $1^{\mathrm{a}}$ & $3.00^{\mathrm{a}}$ & $0.85^{\mathrm{a}}$ & $0.37^{\mathrm{b}}$ & $0.56^{\mathrm{a}}$ \\
\hline$(\mathrm{EPA}+\mathrm{DHA}) / \mathrm{AA}$ ratio in liver (mg/g of liver) & $0.2^{\mathrm{c}}$ & $0.2^{\mathrm{c}}$ & $1.39^{b, c}$ & $2.07^{\mathrm{a}, \mathrm{b}}$ & $0.82^{b, c}$ \\
\hline
\end{tabular}

$\mathrm{AS}=$ Acacia schaffneri; $\mathrm{AF}=$ Acacia farnesiana HFD = High fat diet without goat's milk. $\mathrm{CD}=$ goat's milk from conventional diet. $\mathrm{G}=$ goat's milk from grazing diet. $\mathrm{CD}+\mathrm{AF}=$ goat's milk from conventional diet $+30 \%$ of $A$. farnesiana pods meal diet. ipGTT AUC = intraperitoneal glucose tolerance test area undercurve. ipITT AUC = intraperitoneal insulin tolerance test area undercurve. $\mathrm{SDH}=$ densitometric quantification of muscle succinate dehydrogenase. $\mathrm{ORO}=$ densitometric quantification of Oil red $\mathrm{O}$ staining. $\mathrm{UCP}-1$ = uncoupling protein one. $\mathrm{BAT}=$ brown adipose tissue. $\mathrm{p}$-AMPK $/ \mathrm{AMPK}=$ densitometric analysis of $\mathrm{phospho-AMPK} / \mathrm{AMPK}$ adenine monophosphate (AMP) activated protein kinase ratio. $\mathrm{p}$-JNK/JNK = densitometric analysis of phospho-c-Jun N-terminal kinase JNK/JNK ratio. (EPA+DHA)/AA = (eicosapentaenoic acid + docosahexaenoic acid)/arachidonic acid ratio. Results are presented as the mean, $n=6$ mice per group and evaluated by one-way ANOVA followed by Tukey multiple comparison post hoc test. The differences were considered statistically significant at $p<0.05$. Mean values with different lowercase letters show statistical differences among them. ${ }^{a, b, c, d}$ Means with different letters within rows are significantly different at $\alpha=0.05$.

\section{Discussion}

\subsection{Bioactive Compounds in Vegetation Species Browsed/Grazed by Goats on Semiarid Rangelands}

As previously mentioned, the present review helps to understand the bioactivity and health properties of goat milk and cheese coming from grazing/browsing management. The screening of vegetation of rangeland plant community, revealed a diverse range of occurrence of plant bioactive compound (PBC) and contrasting amounts. The concentrations varied not only on a plant-to-plant basis, but also among plant portions. Such variation in PBC concentration might bring benefits to animals to better keep the balance among nutritional needs, rumen functioning, and food selection [54,55]. This dissimilarity on PBC is positive since animals can select their diet from a wide range of food choices compared to monoculture pastures where food choices are limited by plant species availability.

The variability of $\mathrm{PBC}$ in the animal diet has direct impact on the concentrations of PBC of goat milk (Experiment 2) and cheese (Experiment 5), since a broader variability of phytochemicals was detected in both dairy products from grazing management with respect to indoor management. Therefore, animal production based on grazing/browsing rangeland vegetation seems to be a feasible option for animal keepers not only to feed their 
animals, but also to obtain further benefits such as bioactivity of animal products [5]. In such conditions animals modulate the ingestion of PBC by shifting the selection from low (e.g., leaves and cladodes) to high PBC (e.g., stems and complete plants) concentrations and vice versa [29]. Therefore, intake choices and animal ingestion behavior have direct impact in terms of bioactivity of milk and cheese $[5,10,16,23]$. In these farming conditions, the ability of animals to match food items varying in $\mathrm{PBC}$ to meet nutritional requirements is remarkable, because it must be underneath the threshold of PBC harmful intake [5,23]. Besides, all plant and plant portions displayed antioxidant activity. Broadly speaking, complete plants yielded the best antioxidant performance, followed by fruits, stems, and leaves. In addition, we identified a positive trend between antioxidant activity versus total polyphenol content $(r=0.948)$ and antioxidant activity versus flavonoids $(r=0.890)$. These observations indicate that this outcome could be possible only if other radical scavengers are not present and simultaneously significant contents of TPC and flavonoids are present. This trend can be clearly observed in the pods of A. farnesiana which had the largest total polyphenol content (TPC - 38,170 mg of GAE $/ \mathrm{kg}$ DM) among all assessed vegetation which is combined with high antioxidant activity $(48 \%)$. However, some other feed resources as A. schaffneri with lower TPC (2730 mg of GAE/ $\mathrm{kg} \mathrm{DM}$ ) had similar antioxidant activity $(47 \%)$. This indicates that in the latter plant species, there are other bioactive compounds that were not identified in the present study and that are responsible for the displayed antioxidant activity [20]. Therefore, there is a room for improvement in the characterization of bioactive compounds in the rangeland vegetation with significant antioxidant activity.

\subsection{Bioactive Compounds in Goat's Milk and Cheese}

When we analyzed the antioxidant activity of milk (Experiment 2) and cheese (Experiment 5), a similar pattern as in forages consumed by goats was observed; i.e., antioxidant activity and total phenol content were closely related, where grazing management increased both variables while indoor diets diminished their value. In the same line, the supplementation with a rich source of $\mathrm{PBC}$ forage (A. farnesiana), increase the occurrence of chlorogenic, ferulic and gallic acids as well as catechin in Experiment 2. In grazing management, not only hydroxycinnamic acids and flavonoids concentration were higher in milk and cheese, but there also are some aromatic components such as monoterpenes and sesquiterpenes that described the same pattern (Experiment 3). However, some of them can be lost upon pasteurization [7]. Indoor feeding instead, increased the concentration of specific PCB as ferulic acid, because maize grain, which is included in the indoor diet formulation, is a rich supply of such phytochemical. Apart from nutritional and hygienic quality, hedonic quality is a major driver of consumers food preference [56], a characteristic that would be improved by the occurrence of PBC in milk and cheese products increasing their acceptance [16]. Because of distinct PBC between milk and cheese, it is expected that consumer preference would also be shaped by this effect. Further investigation on this respect should be done to confirm this hypothesis.

A large body of literature has proved that ruminants fed under grazing/browsing management augment the shares of MUFA and PUFA of milk and cheese while decreasing SFA in comparison to conventional feeding $[5-7,12,13,29,33]$. Though this observation was true for most of the experiments reviewed, we observed inconsistent results. For instance, in Experiment 2, we found that milk from indoor diet showed with the top value of PUFA, MUFA and n-3 fatty acids content. Here, a total mixed ratio with good quality ingredients, including Lucerne hay and grain supplement $(60 / 40 \%)$ returned a healthier fatty acid profile. However, conjugated linoleic acid (C18:2 cis-9, trans-11 fatty acid-CLA) in the same experiment was superior in grazing system. The differences could be explained by the distinct biohydrogenation rates as a result of contrasting dietetic ingestion of fatty acids and the dissimilar metabolism of rumen kinetics [1]. In contrast, the value of n-3 fatty acids in Experiments 1 to 5, was numerically superior in grazing systems with respect to indoor diets. Similarly, the n-3/n-6 fatty acid ratio was superior in grazing systems, except in Experiment 3; where indoor diet reported the 
best value ( 0.69 vs. 0.60 , respectively). Good forage quality of indoor diet, particularly Lucerne hay, could be the factor that promoted higher $n-3 / n-6$ fatty acid ratio. In this respect, Simopoulos [57] demonstrated that human diets with a ratio of n-6:n-3 fatty acids of $\sim 1$ promotes better health, whereas higher levels of $n-3$ fatty acids lowered the incidence of chronic maladies. In the same line, Santurino et al. [24] found that the intake of $60 \mathrm{~g} / \mathrm{d}$ of goat cheese enriched with n-3 fatty acids and CLA by obese patients, significantly increased plasma high-density lipoprotein (HDL), and apolipoprotein $B$ at the expense of high-sensitivity $\mathrm{C}$-reactive protein, a nitrogenaceous compound related to inflammation and heart disease. In addition, Fontecha and co-authors indicated that the intake of fat from dairy products has no effect on cardiovascular diseases [22]. In that meta-analysis, milk, butter, cheese, yogurt and kefir consumption conversely may have a slight protective effect to the myocardium. PUFA and MUFA of dairy products should extensively contribute to this outcome. Similar results were reported by Intorre et al. [58] who evaluated cheese made from milk produced by cows fed a grass/maize silage supplemented with five percent of linseed oil. In that study, cheese consumption decreased myristic acid (14:0) and low-density lipoprotein (LDL), both metabolites related to atherogenic events. Thus, grazing/browsing management and rich-PUFA diet of ruminants not only exerts healthy benefits of milk and cheese by increasing the $\mathrm{n}-3$ fatty acid concentration, but also do so for human health. In contrast, a recent publication of Jakobsen et al. [59] underlined a direct relationship between intake of high-fat milk and coronary heart disease (CHD) (per $200 \mathrm{~g}$ higher intake/day; milk intake range: $0-710 \mathrm{~g} /$ day), but no association of low fat milk and $\mathrm{CHD}$ was found. Interestingly, the same study reports an inverse relationship between cheese CHD (per $20 \mathrm{~g}$ higher intake/day) with a cheese intake range from 0 to $120 \mathrm{~g} /$ day. The large heterogeneity of results in that study suggest that some other variables as type of fat or even fatty acid profile should be considered to better interpret the results.

\subsection{Antioxidant and Anti-Inflammatory Activity of Acacia Pods}

Serra and others [16] recently reported that supplementation with polyphenol-rich feeds of animal diets better preserve derived animal products from oxidation and extend the shelf life of food deliveries. In this regard, our group evaluated the transference of bioactivity of two non-conventional natural rich sources of PBC (A. farnesiana and A. schaffneri) in Experiment 6 and Experiment 7. Both Acacia feed resources exhibited significant inhibitory effect on antioxidant capacity. The results reveal that when these rich-PBC forages are included in animal diet, radical scavenger components are transferred firstly from feeds to animal body and metabolism and later to animal products (milk and cheese). Additional benefits of these feeds include the downregulation inflammatory process on ear-edema model in CD-1 mice by A. farnesiana induced after TPA (12-Otetradecanoylphorbol-13-acetate) topical application. The extracts of $A$. farnesiana exhibited significant suppressive effects on interleukins, an inhibitory activity on cyclooxygenase (COX). Likewise, histological analysis demonstrated that pro-inflammatory cytokines as IL$1 \beta$, IL-6, IL-10 and TNF- $\alpha$ were inhibited [31]. All these evaluated parameters corroborate the bioactivity effects of $A$. farnesiana to further impact goat metabolism and dairy products bioactivity [15].

\subsection{In Vivo Prevention of Obesity, Hepatic Steatosis and Insulin Resistance}

Anti-obesity, insulin resistance, inflammation, and hepatic steatosis prevention effects of goat milk come from three feeding regimes namely: conventional diet, conventional diet supplemented with $30 \%$ A. farnesiana and grazing/browsing feeding was assessed. Mice fed high- fat diet supplemented with the tree milk types were able to decrease body weight and body fat mass, improved glucose tolerance, and prevented adipose tissue hypertrophy and hepatic steatosis irrespective of the type of milk. These effects were associated with an increase in energy expenditure, augmented oxidative fibers in skeletal muscle and reduced inflammatory markers [32]. The beneficial effects can be endorsed to polyphenols found in goat milk which augment energy expenditure by modulation of the thermogenic program 
of subcutaneous adipose tissue and activating AMPK activity in skeletal muscle and hepatic tissue of mice [60]. This effect could be associated to the activation of nuclear receptor PPAR $\gamma 2$ which regulates adipose tissue and the metabolism in skeletal muscle by activating the transcriptional program for mitochondrial biogenesis [61]. Consequently, goat milk can be considered as an alternative to modulate the metabolic alterations induced by highenergetic and high-fat diets. The estimations from the body surface area normalization method yielded a conversion equivalent to daily human intake of $250 \mathrm{~mL}$ per glass/day of fresh goat milk for an adult weighing $60 \mathrm{~kg}$ to obtain the claimed benefits [32]. This information can have practical implications for future clinical trials aimed to counteract the effects of obesity and related maladies diseases.

\section{Conclusions}

Grazing/browsing is a useful and inexpensive tool to improve the presence of bioactive compounds and thereby increase the bioactivity of milk and cheese. Rangelands concentrate a wide range of plant bioactive compounds. Grazing/browsing on rangelands is superior to indoor feeding to promote the transference of bioactive compounds from vegetation to animal tissues and finally to animal products. In favorable conditions, an indoor diet might be superior to browsing/grazing management in terms of yielding healthier fatty acid profile by increasing PUFA, MUFA, n-3 fatty acids, and ferulic acid content. However, grazing management represents a better option than indoor feeding to enhance bioactivity of milk and cheese. Supplementation with rich-bioactive compounds forages increases total polyphenol, hydroxycinnamic acids, and flavonoid concentrations in milk and cheese. The consumption of goat milk prevents obesity, insulin resistance, inflammation, and hepatic steatosis.

Author Contributions: Conceptualization C.D.-P. and M.C.-H.; methodology C.D.-P. and M.C.-H.; writing-original draft preparation C.D.-P. and M.C.-H.; writing-review and editing C.D.-P. and M.C.-H. All authors have read and agreed to the published version of the manuscript.

Funding: This review was supported by the funds of the Departamento de Nutrición Animal Fernando Pérez-Gil Romo of the INCMNSZ.

Institutional Review Board Statement: Not applicable.

Informed Consent Statement: Not applicable.

Data Availability Statement: Not applicable.

Acknowledgments: This work was supported by the Departamento de Nutrición Animal Fernando Pérez-Gil Romo of the INCMNSZ.

Conflicts of Interest: The authors declare no conflict of interest.

\section{References}

1. Cabiddu, A.; Delgadillo-Puga, C.; Decandia, M.; Molle, G. Extensive ruminant production systems and milk quality with emphasis on unsaturated fatty acids, volatile compounds, antioxidant protection degree and phenol content. Animals 2019, 9, 771. [CrossRef] [PubMed]

2. Wrage, N.; Strodthoff, J.; Cuchillo, H.M.; Isselstein, J.; Kayser, M. Phytodiversity of temperate permanent grasslands: Ecosystem services for agriculture and livestock management for diversity conservation. Biodivers Conserv. 2011, 20, 3317-3339. [CrossRef]

3. Claps, S.; Mecca, M.; Di Trana, A.; Sepe, L. Local small ruminant grazing in the monti foy area (Italy): The relationship between grassland biodiversity maintenance and added-value dairy products. Front. Vet. Sci. 2020, 7, 1-7. [CrossRef] [PubMed]

4. Rudel, T.; Kwon, O.-J.; Paul, B.; Boval, M.; Rao, I.; Burbano, D.; McGroddy, M.; Lerner, A.; White, D.; Cuchillo, M.; et al. Do smallholder, mixed crop-livestock livelihoods encourage sustainable agricultural practices? A meta-analysis. Land 2016, 5, 6. [CrossRef]

5. van Vliet, S.; Provenza, F.D.; Kronberg, S.L. Health-promoting phytonutrients are higher in grass-fed meat and milk. Front. Sustain. Food Syst. 2021, 4, 1-20. [CrossRef]

6. Galina, M.A.; Osnaya, F.; Cuchillo, H.M.; Haenlein, G.F.W. Cheese quality from milk of grazing or indoor fed Zebu cows and Alpine crossbred goats. Small Rumin. Res. 2007, 71, 264-272. [CrossRef]

7. Cuchillo, H.M.; Puga, D.C.; Navarro, O.A.; Pérez-Gíl, R.F. Antioxidant activity, bioactive polyphenols in Mexican goats' milk cheeses on summer grazing. J. Dairy Res. 2010, 77, 20-26. [CrossRef] 
8. Cuchillo, H.M.; Puga, D.C.; Wrage, N.; Pérez-Gíl, R.F. Feeding goats on scrubby Mexican rangeland and pasteurization: Influences on milk and artisan cheese quality. Trop. Anim. Health Prod. 2010, 42, 1127-1134. [CrossRef]

9. Delgadillo, P.C.; Sánchez, M.B.; Nahed, T.J.; Cuchillo, H.M.; Díaz, M.M.; Solis, Z.R.; Reyes, H.A.; Castillo, D.R.M. Fatty acid content, health and risk indices, physicochemical composition, and somatic cell counts of milk from organic and conventional farming systems in tropical south-eastern Mexico. Trop. Anim. Health Prod. 2014, 46, 883-888. [CrossRef]

10. Salami, S.A.; Luciano, G.; O'Grady, M.N.; Biondi, L.; Newbold, C.J.; Kerry, J.P.; Priolo, A. Sustainability of feeding plant by-products: A review of the implications for ruminant meat production. Anim. Feed Sci. Technol. 2019, 251, 37-55. [CrossRef]

11. Ramírez-Bribiesca, J.E.; Hernández-Cruz, L.; Cruz-Monterrosa, R.G.; Guerrero-Legarreta, I.; Mota-Rojas, D.; Rayas-Amor, A.A.; Domínguez-Vara, I.A.; Avendaño-Reyes, L.; Corona-Gochi, L.; Cuchillo-Hilario, M. The effects of diets containing two corn stubble levels and three non-hydrogenated lipids sources on fattening performance, carcase, and meat quality of male hair-lambs. Ital. J. Anim. Sci. 2021, 20, 406-418. [CrossRef]

12. Mozaffarian, D.; Wu, J.H.Y. Flavonoids, dairy foods, and cardiovascular and metabolic health: A review of emerging biologic pathways. Circ. Res. 2018, 122, 369-384. [CrossRef]

13. Delgadillo, P.C.; Galina, H.M.; Bonilla, C.A.; Cuchillo, H.M.; Montaño, B.S.; Castillo, D.R.; Villareal, E.; Pérez-Gil, R.F. Effect of feeding management on the nutritional composition of Mexican artisan soft cheese made with raw or pasteurized goats' milk. Indian J. Anim. Sci. 2009, 79, 321-326.

14. Delgadillo, P.C.; Cuchillo, H.M.; Pérez-Gil, R.F. Effect of feeding management and seasonal variation on fatty acid composition of Mexican soft raw goats' milk cheese. Ital. J. Anim. Sci. 2009, 8, 402-404. [CrossRef]

15. Delgadillo-Puga, C.; Cuchillo-Hilario, M.; León-Ortiz, L.; Ramírez-Rodríguez, A.; Cabiddu, A.; Navarro-Ocaña, A.; MoralesRomero, A.M.; Medina-Campos, O.N.; Pedraza-Chaverri, J. Goats' feeding supplementation with Acacia farnesiana pods and their relationship with milk composition: Fatty acids, polyphenols, and antioxidant activity. Animals 2019, 9, 515. [CrossRef] [PubMed]

16. Serra, V.; Salvatori, G.; Pastorelli, G. Dietary polyphenol supplementation in food producing animals: Effects on the quality of derived products. Animals 2021, 11, 401. [CrossRef]

17. Innosa, D.; Ianni, A.; Faccia, M.; Martino, C.; Grotta, L.; Saletti, M.A.; Pomilio, F.; Martino, G. Physical, nutritional, and sensory properties of cheese obtained from goats fed a dietary supplementation with olive leaves. Animals 2020, 10, 2238. [CrossRef]

18. Delgado-Pertíñez, M.; Martín-García, I.; Mena, Y.; Zarazaga, L.Á.; Guzmán, J.L. Supplementing the diet of dairy goats with dried orange pulp throughout lactation: Ii effect on milk fatty acids profile, phenolic compounds, fat-soluble vitamins and antioxidant capacity. Animals 2021, 11, 2421. [CrossRef]

19. Zhang, H.; Yu, D.; Sun, J.; Liu, X.; Jiang, L.; Guo, H.; Ren, F. Interaction of plant phenols with food macronutrients: Characterisation and nutritional-physiological consequences. Nutr. Res. Rev. 2014, 27, 1-15. [CrossRef]

20. Quideau, S.; Deffieux, D.; Douat-Casassus, C.; Pouységu, L. Plant polyphenols: Chemical properties, biological activities, and synthesis. Angew. Chem. Int. Ed. Engl. 2011, 50, 586-621. [CrossRef] [PubMed]

21. Santurino, C.; Calvo, M.V.; Gómez-Candela, C.; Fontecha, J. Characterization of naturally goat cheese enriched in conjugated linoleic acid and omega-3 fatty acids for human clinical trial in overweight and obese subjects. PharmaNutrition 2017, 5, 8-17. [CrossRef]

22. Fontecha, J.; Calvo, M.V.; Juarez, M.; Gil, A.; Martínez-Vizcaino, V. Milk and dairy product consumption and cardiovascular diseases: An overview of systematic reviews and meta-analyses. Adv. Nutr. 2019, 10, S164-S189. [CrossRef] [PubMed]

23. Provenza, F.D.; Kronberg, S.L.; Gregorini, P. Is grassfed meat and dairy better for human and environmental health? Front. Nutr. 2019, 6. [CrossRef] [PubMed]

24. Santurino, C.; López-Plaza, B.; Fontecha, J.; Calvo, M.V.; Bermejo, L.M.; Gómez-Andrés, D.; Gómez-Candela, C. Consumption of goat cheese naturally rich in omega-3 and conjugated linoleic acid improves the cardiovascular and inflammatory biomarkers of overweight and obese subjects: A randomized controlled trial. Nutrients 2020, 12, 1315. [CrossRef] [PubMed]

25. Jain, R.; Bronkema, S.M.; Yakah, W.; Rowntree, J.E.; Bitler, C.A.; Fenton, J.I. Seasonal differences exist in the polyunsaturated fatty acid, mineral and antioxidant content of U.S. grass-finished beef. PLoS ONE 2020, 15, e0229340. [CrossRef]

26. Smith, J.; Sones, K.; Grace, D.; MacMillan, S.; Tarawali, S.; Herrero, M. Beyond milk, meat, and eggs: Role of livestock in food and nutrition security. Anim. Front. 2013, 3, 6-13. [CrossRef]

27. Röös, E.; Patel, M.; Spångberg, J.; Carlsson, G.; Rydhmer, L. Limiting livestock production to pasture and by-products in a search for sustainable diets. Food Policy 2016, 58, 1-13. [CrossRef]

28. Galina, M.A.; Puga, D.C.; Hernández, A.; Haenlein, G.F.W. Biodiverse and biosustainable production system with goats in Mexico: Importance of a forage bank. Small Rumin. Res. 1998, 27, 19-23. [CrossRef]

29. Cuchillo, H.M.; Puga, D.C.; Wrage-Mönning, N.; Espinosa, M.J.G.; Montaño, B.S.; Navarro-Ocaña, A.; Ledesma, J.A.; Diaz, M.M.; Pérez-Gil, R.F. Chemical composition, antioxidant activity and bioactive compounds of vegetation species ingested by goats on semiarid rangelands. J. Anim. Feed Sci. 2013, 22, 106-115. [CrossRef]

30. Puga, D.C.; Cuchillo, H.M.; Navarro, O.A.; Medina-Campos, O.N.; Nieto, C.A.; Lopez, T.Z.G.; Díaz, M.M.; Álvarez, I.M.A.; Cruz, Y.R.M. Phenolic compounds in organic and aqueous extracts from Acacia farnesiana pods analyzed by ULPS-ESI-Q-oa/TOF-MS. In vitro antioxidant activity and anti-inflammatory response in CD-1 mice. Molecules 2018, 23, 2386. [CrossRef] 
31. Delgadillo, P.C.; Cuchillo, H.M.; Espinosa, M.J.G.; Medina, C.O.; Molina, J.E.; Díaz, M.M.; Álvarez, I.M.A.; Ledesma, S.J.A.; Pedraza-Chaverri, J. Antioxidant activity and protection against oxidative-induced damage of Acacia shaffneri and Acacia farnesiana pods extracts: In vitro and in vivo assays. BMC Complement Altern. Med. 2015, 15, 1-8. [CrossRef]

32. Delgadillo-Puga, C.; Noriega, L.G.; Morales-Romero, A.M.; Nieto-Camacho, A.; Granados-Portillo, O.; Rodríguez-López, L.A.; Alemán, G.; Furuzawa-Carballeda, J.; Tovar, A.R.; Cisneros-Zevallos, L.; et al. Goat's milk intake prevents obesity, hepatic steatosis and insulin resistance in mice fed a high-fat diet by reducing inflammatory markers and increasing energy expenditure and mitochondrial content in skeletal muscle. Int. J. Mol. Sci. 2020, 21, 5530. [CrossRef] [PubMed]

33. Morales, A.R.; Galina, M.A.; Jimenez, S.; Haenlein, G.F.W. Improvement of biosustainability of a goat feeding system with key supplementation. Small Rumin. Res. 2000, 35, 97-105. [CrossRef]

34. Nahed Toral, J.; López Tecpoyotl, Z.G.; Aguilar Jiménez, J.R.; Grande Cano, D.; Delgadillo Puga, C. Compliance of goat farming under extensive grazing with the organic standards and its contribution to sustainability in Puebla, Mexico. Sustainability 2021, 13, 6293. [CrossRef]

35. Allen, V.G.; Batello, C.; Berretta, E.J.; Hodgson, J.; Kothmann, M.; Li, X.; McIvor, J.; Milne, J.; Morris, C.; Peeters, A.; et al. An international terminology for grazing lands and grazing animals. Grass Forage Sci. 2011, 66, 2-28. [CrossRef]

36. Martirosyan, D.; Kanya, H.; Nadalet, C. Can functional foods reduce the risk of disease? Advancement of functional food definition and steps to create functional food products. Funct. Food Health Dis. 2021, 11, 213-221. [CrossRef]

37. Sharma, O.P.; Bhat, T.K. DPPH antioxidant assay revisited. Food Chem. 2009, 113, 1202-1205. [CrossRef]

38. Taga, M.; Miller, E.; Pratt, D. Chia seeds as a source of natural lipid antioxidants. J. Am. Oil Chem. Soc. 1984, 61, 928-931. [CrossRef]

39. Folch, J.M.; Less, M.; Sloane-Stanley, G. A simple method of the isolation and purification of total lipids. J. Biol. Chem. 1957, 226, 497-504. [CrossRef]

40. AOAC. Official Methods of Analysis, 23rd ed.; Association of Official Analytical Chemists: Washington, DC, USA, 2003.

41. Chen, S.; Bobe, G.; Zimmerman, S.; Hammond, E.G.; Luhman, C.M.; Boylston, T.D.; Freeman, A.E.; Beitz, D.C. Physical and sensory properties of dairy products from cows with various milk fatty acid compositions. J. Agric. Food Chem. 2004, 52, 3422-3428. [CrossRef]

42. Koren, E.; Kohen, R.; Ginsburg, I. Polyphenols enhance total oxidant-scavenging capacities of human blood by binding to red blood cells. Exp. Biol. Med. 2010, 235, 689-699. [CrossRef]

43. Hatano, T.; Kagawa, H.; Yasuhara, T.; Okuda, T. Two new flavonoids and other constituents in liquorice root: Their relative astringency and radical scavenging effects. Chem. Pharmaceut. Bull. 1988, 36, 2090-2097. [CrossRef] [PubMed]

44. Re, R.; Pellegrini, N.; Proteggente, A.; Pannala, A.; Yang, M.; Rice-Evans, C. Antioxidant activity applying an improved ABTS radical cation decolorization assay. Free Radic. Biol. Med. 1999, 26, 1231-1237. [CrossRef]

45. von Gadow, A.; Joubert, E.; Hansmann, C.F. Comparison of the antioxidant activity of aspalathin with that of other plant phenols of rooibos tea (Aspalathus linearis), alpha-tocopherol, BHT, and BHA. J. Agric. Food Chem. 1997, 45, 632-638. [CrossRef]

46. Tsuda, T.; Watanabe, M.; Ohshima, K.; Norinobu, S.; Choi, S.-W.; Kawakishi, S.; Osawa, T. Antioxidative Activity of the anthocyanin pigments cyanidin 3-O-.beta.-D-glucoside and cyanidin. J. Agric. Food Chem. 1994, 42, 2407-2410. [CrossRef]

47. Hernández-Fonseca, K.; Cárdenas-Rodríguez, N.; Pedraza-Chaverri, J.; Massieu, L. Calcium-dependent production of reactive oxygen species is involved in neuronal damage induced during glycolysis inhibition in cultured hippocampal neurons. J. Neurosci. Res. 2008, 86, 1768-1780. [CrossRef] [PubMed]

48. Huang, D.; Ou, B.; Hampsch-Woodill, M.; Flanagan, J.A.; Prior, R.L. High-throughput assay of oxygen radical absorbance capacity (ORAC) using a multichannel liquid handling system coupled with a microplate fluorescence reader in 96-well format. J. Agric. Food Chem. 2002, 50, 4437-4444. [CrossRef] [PubMed]

49. Singleton, V.L.; Orthofer, R.; Lamuela-Raventós, R.M. Analysis of total phenols and other oxidation substrates and antioxidants by means of Folin-ciocalteu reagent. Methods Enzymol. 1999, 299, 152-178.

50. Del-Ángel, M.; Nieto, A.; Ramírez-Apan, T.; Delgado, G. Anti-inflammatory effect of natural and semi-synthetic phthalides. Eur. J. Pharmacol. 2015, 752, 40-48. [CrossRef]

51. Delgadillo, P.C.; Castillo, D.R.M.; Cuchillo, H.M.; Díaz, M.M.; Pérez-Gíl, R.F.; Montaño, B.S. Radical scavenging activity and health and risk fatty acid indices of soft goats' milk cheeses. Arch. Latinoam. Prod. Anim. 2015, 23, 21-26.

52. SAS. Statistical Analysis System. User's Guide, 1st ed.; SAS. Institute Inc.: Cary, NC, USA, 2003; p. 120.

53. IBM Corp. Released 2010. IBM SPSS Statistics for Windows, Version 19.0; IBM Corp: Armonk, NY, USA, 2010.

54. Cuchillo, H.M.; Wrage-Mönnig, N.; Isselstein, J. Behavioral patterns of (co-)grazing cattle and sheep on swards differing in plant diversity. Appl. Anim. Behav. Sci. 2017, 191, 17-23. [CrossRef]

55. Cuchillo, H.M.; Wrage-Mönnig, N.; Isselstein, J. Forage selectivity by cattle and sheep co-grazing swards differing in plant species diversity. Grass Forage Sci. 2018, 73, 320-329. [CrossRef]

56. Juárez-Silva, M.E.; Cuchillo-Hilario, M.; Villarreal-Delgado, E. Dietary supplementation of inulin or flavomycin and type of cut of meat: Effects on fatty acid profile, sensorial characteristics and consumer preference of rabbits meat. Rev. Mex Cienc. Pecu. 2019, 10, 552-570. [CrossRef]

57. Simopoulos, A. An increase in the omega-6/omega-3 fatty acid ratio increases the risk for obesity. Nutrients 2016, 8, 128. [CrossRef] [PubMed] 
58. Intorre, F.; Foddai, M.S.; Azzini, E.; Martin, B.; Montel, M.-C.; Catasta, G.; Toti, E.; Finotti, E.; Palomba, L.; Venneria, E.; et al. Differential effect of cheese fatty acid composition on blood lipid profile and redox status in normolipidemic volunteers: A pilot study. Int. J. Food Nutr. Sci. 2011, 62, 660-669. [CrossRef]

59. Jakobsen, M.U.; Trolle, E.; Outzen, M.; Mejborn, H.; Grønberg, M.G.; Lyndgaard, C.B.; Stockmarr, A.; Venø, S.K.; Bysted, A. Intake of dairy products and associations with major atherosclerotic cardiovascular diseases: A systematic review and meta-analysis of cohort studies. Sci. Rep. 2021, 11, 1303. [CrossRef]

60. Palacios-González, B.; Vargas-Castillo, A.; Velázquez-Villegas, L.A.; Vasquez-Reyes, S.; López, P.; Noriega, L.G.; Aleman, G.; Tovar-Palacio, C.; Torre-Villalvazo, I.; Yang, L.J.; et al. Genistein increases the thermogenic program of subcutaneous WAT and increases energy expenditure in mice. J. Nutr. Biochem. 2019, 68, 59-68. [CrossRef] [PubMed]

61. Avior, Y.; Bomze, D.; Ramon, O.; Nahmias, Y. Flavonoids as dietary regulators of nuclear receptor activity. Food Funct. 2013, 4, 831-844. [CrossRef] 